\title{
Reading Karl Barth on Truth and Falsehood in the Post-Truth Age
}

\author{
Geoff Thompson (1D
}

Pilgrim Theological College, University of Divinity, Parkville 3052, Australia; geoff.thompson@pilgrim.edu.au

\begin{abstract}
This article offers a close reading of two sections of Karl Barth's Church Dogmatics, i.e., §70.1 "The True Witness" and §70.2 “The Falsehood of Man" against the background of the post-truth environment. A brief discussion of the post-truth phenomenon highlights how some strands of the resistance to it trade on a binary of objective and subjective approaches to truth and epistemology, insisting on the triumph of the former over the latter as the way of overcoming the problems of knowledge and truth in a post-truth culture. The reading of the two selected texts from the Dogmatics indicate that Barth's discussion of truth and falsehood cuts across that binary. Whilst much of what Barth says in these texts is said in earlier parts of the Dogmatics, it is sharpened in this context by Barth's discussion of the "pious lie," the distortion of the truth within the Christian community, as the fundamental form of falsehood. Alertness to this sin challenges the church to adopt a posture of self-criticism to its own knowledge of the truth. This can be its own form of witness in the post-truth age.
\end{abstract}

Keywords: Karl Barth; truth; falsehood; post-truth

check for updates

Citation: Thompson, Geoff. 2021. Reading Karl Barth on Truth and Falsehood in the Post-Truth Age. Religions 12: 593. https://doi.org/ $10.3390 /$ rel12080593

Academic Editors: Mark R. Lindsay and John McDowell

Received: 21 June 2021

Accepted: 27 July 2021

Published: 31 July 2021

Publisher's Note: MDPI stays neutral with regard to jurisdictional claims in published maps and institutional affiliations.

Copyright: (C) 2021 by the author. Licensee MDPI, Basel, Switzerland. This article is an open access article distributed under the terms and conditions of the Creative Commons Attribution (CC BY) license (https:/ / creativecommons.org/licenses/by/ $4.0 /)$.

\section{Introduction}

The concept of truth has never been self-evident. Nevertheless, that it has provoked the vigorous, probing and enduring debates and discussions that it has within Western culture is in large measure because there has been a broad cultural consensus that the concept points to something real and which, notwithstanding various limits, is knowable. This consensus has, of course, never been without its dissenters, and it has been significantly disrupted within the West's intellectual world for some time, whether by the post-modern impulses towards epistemological relativism or the post-metaphysical suspicion towards any unifying objective reality. This disruption, common to the intellectual world, has nevertheless now transferred to wider cultural realms with the emergence of the various factors which have led to the current era being designated "post-truth." With this cultural development, it is not just that in this culturally plural world there are different accounts of truth, but that conventions employed to demonstrate or articulate any truth claim have been stripped of their cultural legitimacy. Truth claims are not simply to be debated, they are not to be trusted. Truth claims are tools—consciously or otherwise-of those making the claims for self-interest and are immune to either self- or external scrutiny. Herein lies a particular moment of crisis for contemporary post-truth Western culture: can anyone who makes truth claims be trusted, and are those who make truth claims licensed to insulate themselves from scrutiny and critique?

In this paper I will draw on elements of Karl Barth's theology as a resource to address some of these binaries and propose a particular posture on the part of Christians towards their knowledge and proclamation of the truth. No attempt will be made, however, to offer a comprehensive account of Barth's understanding of truth. Rather I will draw on two adjacent sections of Church Dogmatics where Barth explores, respectively, Jesus Christ as the true witness and the sin of falsehood, i.e., \$70.1 "The True Witness" and \$70.2 “The Falsehood of Man" (Barth 1961, pp. 368-461) ${ }^{1}$. The posture proposed will not be an apologetic for the content of Christian truth. Rather it will be set forth as a mode of engaging the truth of Jesus Christ which might subvert the suspected nexus between truth-claims, self-interest and 
resistance to scrutiny. Nor will it be oriented towards defending the Christian doctrine of revelation (whether Barth's or that of any other theologian) as the justification of Christian truth claims. Rather, the focus will be on the mode of engagement that this self-witness of Jesus Christ invites. The mode of engagement will itself be offered as a mode of Christian witness in a world where truth is treated with suspicion. To develop this proposal, the paper will proceed in three sections. First, I will briefly survey the definition, discussions of, and responses to, the idea of post-truth. Secondly, I will offer an exposition of the two relevant sections of the Dogmatics. Finally, prompted by Barth's ideas, I will make some proposals for Christian engagement with public discussion of truth in a post-truth context.

\section{Post-Truth}

Descriptions of the current era as one of post-truth are now commonplace. In famously awarding it the status of "word of the year" in 2016, Oxford Dictionaries defined the term as an adjective "relating to or denoting circumstances in which objective facts are less influential in shaping public opinion than appeals to emotion and personal belief" (Oxford Languages 2016). The cultural and political consequence of this approach to truth are writ large in recent history, not least on a global scale, with the election and subsequent presidency of Donald Trump being the most emblematic events of this phenomenon. At stake is not just this or that theory of truth, but the capacity for truthful collective engagement with and responses to reality. Journalism is undermined as fake news; spin is normalized as a substitute for political discourse and policy development; expertise is maligned because it is, well, expert. The latter manifests itself most sharply, and alarmingly, in the politically charged climate change denialism.

Of course, the advent of the post-truth age was not required for denials of truth or debates about it. Such debates have been vigorous in the modern West as its erstwhile unifying narratives (whether based on Christian revelation or the Enlightenment's rationalism) have given way to the realities of diverse notions of truth and/or different visions of reality contesting with each other, and sometimes finding variously easy or uneasy ways of co-existing. These are manifest in debates between realists and non-realists, modern rationalists and post-modernists, analytic philosophers and philosophical pragmatists.

What, however, is characteristic of the current epoch is the cultural and political legitimacy afforded to the dismissal or disregard of such conversations. Rowan Williams observes that with these and similar developments, the West has moved into a "'dark night' for intelligence" (Williams 2016, p. 23), a time in which "we don't quite know what knowing is for and we don't even know that we can know" (ibid.). Yet even such a description seems too benign. The extent of the problem is arguably better captured in Lee McIntyre's claim, in his Post-truth, that "[O]ne gets the impression that post-truth is not so much a claim that truth does not exist as that facts are subordinate to our political point of view" (McIntyre 2018, p. 11). He goes on to point out the high stakes at issue when such a view is adopted: "This post-truth amounts to a form of ideological supremacy, whereby its practitioners are trying to compel someone to believe whether there is good evidence for it or not. And this is a recipe for political domination" (ibid., p. 13). With these remarks, McIntyre echoes Hannah Arendt's much-quoted and incisive mid-twentieth-century observation in her The Origins of Totalitarianism that the "ideal subject of totalitarian rule is not the convinced Nazi or the convinced communist, but people for whom the distinction between fact and fiction (i.e., the reality of experience) and the distinction between true and false (i.e., the standards of thought) no longer exist" (Arendt 2017, p. 622).

Responding to the gravity of the situation (even before the term post-truth was coined), responses have included exposés of how commercial interests (in the case of the American tobacco industry) sowed doubts about the reliability of scientific research for the sake of financial gain (McIntyre 2018, pp. 17-34), philosophical critiques of postmodern theories which allegedly license post-truth discourse (Bogghasian 2006; Frankfurt 2005), and vigorous defenses of the factual, over subjective emotion and opinion, as the guarantor of a truthful engagement with reality. Prominent among the latter is Stephen Pinker's En- 
lightenment Now (Pinker 2018). Pinker attacks various "Counter-Enlightenments", namely, religion, nationalism and what, echoing C.P. Snow's famous "two cultures" of science and the humanities, he terms "second culture." All these, he contends, are manifestations of the various forces which, especially in the form of Romanticism, resisted the Enlightenment from its beginning (ibid., pp. 29-35). Moreover, they still do so in the form of contemporary "intellectuals and critics" who write as if "the consumption of elite art is the ultimate moral good" (ibid., p. 34). Pinker also, albeit in passing, resists what he regards as the cliché of the term "post-truth." It is a term that should be retired, he argues, because to the extent that it points to mendacity, conspiracy theories, and the madness of crowds, it is "as old as our species" (ibid., p. 375). For Pinker, truth is guaranteed by reason, which empirical evidence generated by scientific investigation of the world is both a manifestation and tool. Indeed, the connection is quite straightforward: "Science, in the modern conception ... is of a piece with reason itself" (ibid., p. 392). Such investigation exposes "traditional causes of belief" as wrong: "[W]e must allow the world to tell us whether our ideas about it are correct. The traditional causes of belief-faith, revelation, dogma, authority, charisma, conventional wisdom, hermeneutical parsing of texts, the glow of subjective certainty-are generators of error, and should be dismissed as sources of knowledge" (ibid., p. 393). Accordingly, "the findings of science imply that the belief systems of all the world's traditional religions and cultures-their theories of the genesis of the world, life, humans and societies-arefactually mistaken." (ibid., p. 394). Moreover, Pinker is concerned not only about the "traditional causes of belief" and their errors, he is also concerned about the link between belief, group identity and the capacity for criticism. Thus, he asserts: "[W]e have seen that when a creed becomes attached to an in-group, the critical faculties of its members can be disabled, and there are reasons to think that has happened within swathes of academia" (ibid., p. 373). Empirical truth becomes a tool against "belief" and the insularity it can foster.

For all that he resists the term "post-truth," Pinker nevertheless reinforces the categories by which the Oxford Dictionaries define it: the objective truth that must correct emotion and personal beliefs of post-truth is deemed to be straightforwardly factual and empirical. Empiricism is thus said to rescue the post-truth culture from the subjective and emotive. As such, so it is claimed, it can rescue the culture from the insular certainties, and even arrogance, which often attach to the so-called subjective. By extension, religion, understood as belonging to the domain of the non-empirical, becomes the target of empirical scrutiny and is proved 'mistaken' by that scrutiny. Pinker thus simply re-states and, with his own particular rhetoric reinforces, a conventional divide found in post-Enlightenment discussions of truth. Certainly, the empiricism Pinker advocates may well be one tool in combatting post-truth distrust of truth claims. However, other tools may include richer concepts of truth, precisely those rejected by Pinker. Indeed, precisely by reinforcing this binary, Pinker himself is vulnerable to the charge of resisting scrutiny of his own claims about the priority of the empirical. ${ }^{2}$ Either side of the binary detached from the other can, to echo Lee McIntyre's comment quoted earlier, be "a recipe for domination".

So far as it has set the terms for responding to the problems of the post-truth phenomenon, the Oxford definition is deeply problematic in shaping what counts as truth and in regard to which approaches to it will foster discussions about it in culturally and intellectually plural societies. If the contemporary challenge is to foster postures towards the concept of truth which facilitate, rather than shut down, conversations about it, then the binary of an objective empiricism and subjective emotion will need to be subverted. However, the other issue to emerge from this brief survey is the fear that absent some empirical reference point, other modes of exploring and articulating the true truth will necessarily lead to insulation or, as alleged by Pinker, to the abandonment of critical faculties. This is not resolved by privileging the objective over the subjective or by confining intellectual enquiry to that binary. What is needed, instead, is a wider discussion which links objectivity, subjectivity, certainty and self-criticism. Post-truth invites questions not simply of epistemology but also about the virtues, and even the spirituality, of knowledge. 
On the one hand, Christian faith itself has often been caught in that binary between the objective and subjective, simply substituting revelation or scripture for empirical fact as the corrective to the subjective and emotive. Alternatively, doctrines of revelation and/or scripture are invoked to rescue theological method from the ambiguity or alleged excesses of experience. On the other hand, feminist and other contextual theologies have been exposing the inevitability of experience in the production of theological knowledge and in constructively appropriating it into theological epistemology. The post-truth binary-and the anxiety about experience that it has generated-places that constructive appeal to experience under significant pressure, as it does the even more recent discussions of the role of the emotions in theology (Zahl 2020). In the particular context of this paper, it needs to be acknowledged that Barth's theology was itself a source of reinforcing that very binary by privileging revelation throughout twentieth-century debates about theological method. ${ }^{3}$ It is, therefore, important to stress that what follows here is not an attempt to rescue Barth from that particular debate, or to defend his position within it. Rather, it is to insert Barth's quite specific discussion of Christ as the true witness to the truth and human sin of falsehood into the wider challenge of navigating between objectivity, subjectivity, certainty and self-criticism. I will argue that Barth's unapologetic and insistent Christological focus, far from flattening the relationship between these realities, helps to bring them into a particular combination which, in turn, generates a posture of conviction and humility on the part of Christians. On its own this will not, of course, cure the malaise of a post-truth world, but it can suggest modes of Christian witness which respond to that malaise.

\section{Exposition of $\S 70.1$ Christ as the True Witness and §70.2 The Falsehood of Man}

Many of the themes to be explored in what follows are well-established threads in the fabric of Barth's theology. They happen to be inflected in these particular texts as part of Barth's third treatment of sin within what is itself the third part of his doctrine of reconciliation. Here Barth explores sin as falsehood. Three comments about this context and theme are necessary. First, in this third part of the doctrine of reconciliation-itself headed "Jesus Christ, the True Witness"-Barth is concerned with how Christ's work of reconciliation at a particular time and place (the topic of the first two parts of this doctrine) is made present to all times and places. The short answer to this question is that the risen Jesus, in the power of the Spirit, "speaks for Himself, that He is His own authentic Witness, that of Himself He grounds and summons and creates knowledge of Himself and His life, making it actual and therefore possible" (Barth 1961, p. 46). ${ }^{4}$ As Barth develops this theme, he articulates and consolidates his rejection of all ecclesial and anthropological grounds of mediating Christ's presence. The second comment is that throughout the three parts of the doctrine of reconciliation, Barth takes up the theme of sin only after he has discussed Christology. ${ }^{5}$ In the first two parts, Christ the "Obedient Son of God" and Christ as the "Exalted Son of God" provide the foundations for his respective accounts of sin as pride and sloth. Now, in this third part, Christ as the "True Witness," Barth lays the foundation of sin as falsehood. Thirdly, a striking feature of his treatment of these themes is his use of the book of Job, and his presentation, on the one hand, of Job as a "type" of Jesus Christ and, on the other hand, of Job's interlocutors as the "classic documentation" of falsehood. This use of the book of Job, and Barth's particular interpretation of it, has generated considerable discussion (Ticciati 2005; Lewis 2014). For the purposes of this present exposition, however, I will limit my own reference to it to Barth's discussion of the falsehood of Job's interlocutors. With this summary of context and theme in place, I will now set out the main claims of these two texts.

Three questions drive §70.1: What is truth? In what form do we encounter the truth? On what basis is truth known? The questions overlap with each other, as do the answers Barth gives them.

What is truth? Barth's straightforward and characteristic answer to his question is Jesus Christ. Yet the force of this answer is intensified by both the more specific content he 
gives it and with what he contrasts it. Its specific content is the full event of reconciliation which, as the human being who is fully one with God, Jesus Christ, is. For Barth, the "true Witness, and therefore the pronouncement, revelation and phenomenon of the truth, the truth itself ... is the living Jesus Christ present in the reconciled word in the promise of the Sprit and acting in and towards it in exercise of His prophetic office" (Barth 1961, p. 378). In this particular life, there is no abstract union of humanity and divinity: in it, the "free God and free man meet and are one in Him" (p. 383). This dynamic and reconciling unity is the truth: "[I]n this relationship to this man God is the true God, i.e., God in the authentic revelation of His divine nature, God as He is. And in this relationship to God man is true man, i.e., man in faithful confession of His humanity, man as he is. The meeting of this revelation of God and this confession of man is truth in the full sense of the term" (pp. 379-80). As such, there are certain ways that truth might be understood which are ruled out. "It is not," Barth writes, "an idea, principle, or system ... Nor is it a structure of correct insights, nor a doctrine" (p. 375). To be sure, there can be true doctrines, but "[e]ven at best, doctrine as the work of man is always a dubious and equivocal phenomenon" (p. 376). Yet, not only can doctrine be equivocal, it can have its own particular proximity to falsehood: "the more a doctrine seems to be abounding in correct insights the more we have cause to suspect that what is trying to claim and enslave us is an idea, principle, system or doctrine of falsehood" (p. 376).

In what form is truth encountered? Barth addresses this question alert to the way his answer to the first could be exposed to the charge of Docetism. This leads him to emphasise the continuity of form between the event of reconciliation itself as well as in its contemporary witness. Thus, Jesus Christ's self-witness of reconciliation "should correspond to its content, and therefore ... the prophetic work of Jesus Christ should have the form of passion" (p. 390). From the resurrection onwards, Barth argues, Jesus Christ "has continually proffered Himself to the Church and the world in this form. He encounters us in this form or not at all. To look past it is not to see Him" (pp. 390-91). This has implications for the reception of this truth. It is unsettling of conventional notions of truth, and it invites suspicion now no less than when it was first revealed. Jesus Christ remains "the Friend of publicans and sinners whose very family think that He is mad, who is accused of blasphemy and sedition, who is reckoned with malefactors and crucified with them, who is forsaken by His disciples and our God" (p. 396). Moreover, it invites not only suspicion, but ridicule:

He does not fit but completely contradicts the picture which man has of a bringer of good news, and especially of one who brings such conclusively good news, and proclaims himself as its content.... It was only too easy to despise the suffering and afflicted Jesus Christ as the Witness to truth, and if He is still the same to-day as yesterday the temptation is just as strong to-day and always to say: 'Save thyself ... ". (p. 391)

That the response to this truth can be suspicion and ridicule manifests the fact that the opposition to this truth has not grown weaker in this post Christum time: "The sphere of our time and history is not, then, the theatre of a decrease of darkness, as we might suppose, but rather its intensification and increase" (p. 392). In sum, the truth is not "a phenomenon which is immediately and directly illuminating, pleasing, acceptable and welcome" (p. 376).

On what basis is truth encountered? This, of course, is the presenting question of the earlier sections of this third part of the doctrine of reconciliation. However, it is now heightened and intensified by Barth's emphasis on the unsettling nature of truth. In returning to it Barth is no longer simply addressing a formal matter of the priority of revelation or the priority of the actual over the possible. It is a question of how this unsettling and confronting message comes to be heard and appropriated as truth. How is it that the word of reconciliation is spoken from the death of this man? For Barth, it is not just that God overcomes the creator-creature difference in order to make this truth known. If the passion of Jesus is the form in which this truth is known, then the silence 
of death is to be overcome: "God alone as the only Lord of life and death can break this silence, and therefore speak out of this end and limit of all human words" (p. 410). Thus, "the crucified, dead, and buried man Jesus Christ does speak. Those who hear Him hear God" (p. 411). Ultimately, this is the work of the Holy Spirit: "The Holy Spirit is simply but most distinctly the renewing power of the breath of His mouth which as such is the breath of the sovereign God" (p. 421). Yet just as the Holy Spirit's work overcomes the power of death in making this truth known, and thus the accounts for the how of this encounter, it also disrupts the possibilities of where in the human experience it might be known. Being the truth it is and the form it takes means that it is not encountered "where we think we should look for Him, namely, in a supposed height," but rather "in direct confrontation with and at the very heart of our own reality" (p. 416) of being forsaken and alone. Thus is Jesus Christ, the true witness encountered as "Neighbour and Brother suffering with and for" human beings (p. 416).

In turning now to $\$ 70.2$, "The Falsehood of Man", we turn to the aspect of sin which is provoked by Jesus Christ, the true witness. Falsehood does not "take form in a vacuum ... but only in relation to Him" (p. 434). Fundamentally, it is "a movement of evasion" (p. 434) which consists of "trying to find another place where the truth can no longer reach" (p. 435). Arguably the most striking aspect of Barth's discussion of this topic derives from the fact that falsehood is precisely defined by its reaction to the word of reconciliation declared by the living Jesus Christ. It is, Barth contends, "the form of sin which properly speaking is possible and powerful only in this age" (p. 435). As already highlighted above, the time post Christum is not a time of the necessary lessening of darkness. Moreover, it is the Christian community itself, the sphere where this truth is known, which is where the evasion can be most acute. Christians must "confess that they themselves are the ones to whom it applies first, that in them as Christians the unbelief, superstition and error, and therefore the falsehood of man, have their true and original form" (p. 451). Direct acquaintance with this knowledge can provoke its domestication, whether by retaining - but blunting-the message of the cross or by retaining a discourse about 'God' whilst replacing the living God within the discourse with a supreme divine being. Whatever its form, such domestication may well have the appearance of truth, but it is actually falsehood's attempt to control God and thus to reject the freedom which the work of reconciliation offers. It is on this point that the excursus on Job is most illuminating. Barth acknowledges that although Job's pious friends speak "unquestionably ... good, earnest and religious words" (p. 453), they nevertheless manifest the "pious lie" (ibid.) by taking something true and turning it into a lie:

[T]he friends speak about God and Job in terms which are strikingly unhistorical. They preach timeless truths, truths which were once lit up as concrete Words of God and therefore as genuine truths in the context of the history of Israel ... but which in abstraction can only live on and bloom like cut flowers. Even when they address Job directly, they simply put before him deductions from these timeless truths ... In Job's speeches [in contrast] we are plunged into the strain and stress of the ongoing history of Yahweh with him. Everything that he says, whether right or wrong, is baptised in the fire of a painful encounter with Him.... [The friends] speak as those who are totally unaffected by the tension, which stirs Job so profoundly. (pp. 457-58)

To return to Barth's main point about the way falsehood domesticates: its impact is not limited to the Christian community. It extends to the 'secular' world: "The worst of weekday lies has its roots in the even worse Sunday lie, the profane in the Christian." (p. 451). Strikingly, the most specific example of this secular manifestation of the pious lie is "the press." The passage is worth quoting at length.

When and where has there been opened such a gigantic maw of lying as the so-called 'press,' which to-day with its exaggeratedly bright or gloomy imparting of news, its interpretations, insinuations, commendations and calumniations in the service of a one-sided interest, at once the slave and the master of public 
opinion, is the word which is drummed into the ears of all of us every day, and is obviously meant to be "impressed" upon our minds and hearts and consciences? And all this is planned and contrived by baptised and more or less believing Christians, not in a heathen world, but in more or less close confrontation with the Gospel of Jesus Christ. (p. 452)

This proximity of piety and falsehood, and the impact of that proximity, places a responsibility for self-examination on the Christian community. If it cannot see the lie at the heart of its own life, it will not see it at the periphery, let alone beyond the periphery. Accordingly, "Christianity has again good cause to beat its own breast before it can describe as falsehood the falsehood of the world, the common lie, and before it can make honest use of the truths of the world. There must be light in itself before there can be more light in the world" (p. 453).

Of course, the resonance between Barth's reference to "the press" of the late 1950s and the contemporary rhetoric about "fake news" is quite striking, especially in view of the theme of this paper. It should be read carefully, however. The latter is invoked to demonise particular strands of the media in order to legitimate other strands. It is a political weapon used to polarise. The former is used as one example of the power of falsehood. It is a spiritual diagnosis used to prompt self-criticism on the part of Christians. In the end, regardless of the particular example used by Barth, this is the concluding point of $\S 70.2$ : the confrontation between truth and falsehood exists in the very act of knowing the truth. Yet it is not a confrontation that is doomed, and nor is it one which overwhelms human response. Such is the exhortation of the section's final sentences.

Concerning the spreading of light in the world, and the destruction of the common lie, we need not be finally anxious in the light of the promise which speaks with living power at this centre. Nor, if we look in this direction, need there be lacking in us the courage which we need in the service of this spreading of light and therefore in conflict even with the common lie. (p. 453)

In summing up the above exposition of the two selected texts, several points relevant to the following discussion can be highlighted. First, the entire discussion presupposes Barth's axiomatic priority of the actual over the possible. The possibly of knowing the truth lies only with God making it known. Controversial though this aspect of Barth's theology is, Barth does nothing in these texts to lessen the controversy. Yet nor is their argument a mere repetition of an epistemological point already established in Barth's theology. The particular juxtaposition of truth and falsehood in what is in fact a discussion of sin allows some well-established themes to be presented in fresh ways and in fresh combinations. Secondly, by defining truth in terms of Jesus Christ's self-attesting life, Barth reinforces that truth can never be reduced to a principle, formula or even a doctrine. Thirdly, as truth is this particular life which takes the form of passion, it does not conform to expectations and it disrupts those expectations. Fourthly, with this disruptive impulse the truth provokes those who know it to domesticate it and to be ever prone to turning the truth into a falsehood. To the relevance of these considerations to the post-truth phenomenon, I now turn.

\section{Appropriating Barth in a Post-Truth Context}

In the first section of this paper, I argued that aspects of the post-truth discussion had themselves reinforced a conventional, if especially modern, binary between the objective and subjective in relation to matters of truth and the knowledge of it. With so much of the post-truth phenomenon fuelled by the rejection of, or suspicion towards, factual knowledge, some prominent attempts to deconstruct the post-truth culture were confining their efforts to the privileging of so-called objective facts as the guarantor against the biases and alleged insularity of the subjective. I suggested that rather than working within that binary, let alone trusting it as definitive, a more robust engagement with a wider range of reference points and their inter-relationships was necessary, i.e., objectivity, subjectivity, certainty and self-criticism. In this context, it is the combination of these points of reference 
in the selected texts just studied which mark these texts of Karl Barth as an interesting resource.

Of course, it would be possible to complete this paper by drawing connections between these two texts and Barth's later accounts of the forms of Christian witness which correspond to the true witness, Jesus Christ, and to explore how those forms of witness engage a post-truth world. ${ }^{6}$ Yet, as I will seek to show, there is merit in Barth's ideas in the discussion of truth and falsehood which have relevance beyond how Barth himself builds on them. That they do so emerges from the spiritual and contested nature of knowing the truth which Barth highlights. Indeed, it is this feature of Barth's argument that makes them even more problematic to the conventional objections to the knowledge grounded in faith. This point can be made by considering the following remarks (which, although not themselves commentary on Barth, do have Barth's theology in the background) from Craig Hovey.

Christian witness is eminently vulnerable, exposed, laid bare before the exigencies and strains of the world. It abjures prior rational justifications of both its central premises and its exercise as a mode of knowledge at risk of disqualification against the demands of modern epistemology. (Hovey 2011, p. 230)

Yet what Barth's discussion of truth and falsehood highlights is the way that the knowledge of the true witness is at risk, not simply of philosophical disqualification, but of distortion by the very community which is given to know it. Accordingly, the possession of knowledge is accompanied not simply by a humility in the face of mystery or of a generic apophatic impulse. Rather, as we saw in the exposition of Barth's idea of falsehood, it is accompanied by self-criticism in the face of the sin of falsehood. Herein, I suggest, is the point at which Barth's theology can prompt the Christian community to consider its posture towards the truth amidst the pressures of the post-truth environment, and with that posture bear its own witness to the anxieties of those seeking to remedy the post-truth malaise by asserting allegedly objective knowledge as the guarantor against the insularity of the subjective.

At face value, Barth's structuring of his discussion about the truth that Jesus Christ is by the priority of the actual over the possible appears to transfer the objectivity of the object of the knowledge to the knowledge of the knower. This seems to form a very strong set of connections between knowing the truth and certainty about that truth. The spiritual nature of this knowledge would, moreover, make it a prime target for the empiricists criticisms of such knowledge claims. Furthermore, that truth is so singularly defined by Jesus Christ may compound the suspicion that the Christian community is totally insular and lacking any resources for self-criticism of its knowledge of truth. Certainly, there is no shortage of Christian communities which lack such self-criticism, and aspects of Barth's rhetoric may be an all too easy tool to license their insularity. However, Barth's idea of sin as falsehood which is provoked by the advent of Jesus disrupts these connections, and it does so precisely at the point where they might seem at their strongest. To be open to this disruption does not require Christians to jettison the idea of the givenness of their knowledge of Jesus Christ as the truth, but it can provoke an acute awareness that the Christian community has not yet been granted the full victory over sin which Jesus Christ has achieved. Certainly, Christian faith does hope in that ultimate victory, but, again to quote Craig Hovey, the "Christian confidence in the truth's ultimate triumph also frees the witness from rushing the events that lead to that victory and from violently interposing one's zealous agenda in order to bring it about" (Hovey 2011, p. 148). There is no divine promise attached to the knowledge of Jesus Christ that his victory over sin transfers to the Christian knowledge of him in this time of his prophetic office. There is, instead, an alertness to the capacity to domesticate and distort that knowledge, to minimise its disruptive impulses, and thus to a need for self-criticism of its own witness to that truth. To return to the passage quoted from Barth earlier: the Christian community has good cause to beat is own breast before it can describe as falsehood the falsehood of the world and before it can make honest use of the truths of the world. This raises the question of 
just what Barth might mean by the "truths of the world" and what it would mean to "use" them. Barth does indeed have developed ideas on these matters (Barth 1961, pp. 113-65). Yet they are not the presenting issue here. Rather, the presenting issue is the posture of the Christian community to its own knowledge of the truth in a post-truth world. In this world, quests to resist the subjective, emotive and communal on the one hand, and quests to expose and exploit the ambiguities in all appeals to some or another universal objective on the other hand meet each other in mutual suspicion.

Drawing on the ideas of Barth explored here, the church can be construed as a community where that mutual suspicion is refracted as a particular mode of self-directed suspicion, or at least scrutiny, before it directs any such suspicion to the world beyond its own life. Ultimately, the church's vocation is to proclaim the truth that Jesus is as the truth. However, it also has a penultimate task of bearing witness to that truth in a mode that reflects the content of the knowledge and the spiritual limits on its capacity to know this truth. This posture itself is a form of witness. The post-truth crisis is not an epistemological one in any abstract sense. It is a crisis of different postures towards the truth, and of different cultural performances of what is held to be the truth. As it performs its knowledge of Jesus Christ, the Christian community can offer a mode of confident knowledge that does not require the validation of that knowledge through domination. It can offer a mode of knowledge which whilst unapologetically particular is also intrinsically self-critical. As a form of witness, it cannot escape its own fragility. The polarities of the post-truth world may or may not notice this witness, but it could be a form of serving the post-truth world precisely by challenging those polarities and thus provoking different questions about truth, and allowing the church humbly and self-critically to confess its knowledge of Jesus Christ, the true witness.

Funding: This research received no external funding.

Conflicts of Interest: The author declares no conflict of interest.

\section{Notes}

1 Unless otherwise indicated, all subsequent references to the the Church Dogamtics are from this volume and will be indicated by page number alone.

2 On this, see Arne Rasmussen, in a critique simultaneously directed at Pinker and George Lakoff: "They seldom reflect on the hermeneutical issues raised by the way they combine their scientific expertise with social and political theory, historical constructions, and ontological and moral assumptions. The habits of mind created within their own scientific fields continue to shape how they analyze and argue when they proceed to do political and moral analysis" (Rasmussen 2012, p. 222).

3 For a recent account of Barth's position and its influence, see (Zahl 2020, pp. 26-35).

4 Barth is here expounding within the doctrine of Christ's prophetic office what he has already developed at length in the discussion of the knowledge of God (Barth 1956, pp. 3-254).

5 For Barth's explanation and justification of this approach, see (Barth 1968, pp. 358-413).

6 See especially \$72.1, "The People of God in World Occurrence" and §72.2, "The Community for the World," (Barth 1962, pp. 681-62 and 762-95).

\section{References}

Arendt, Hannah. 2017. The Origins of Totalitarianism. London: Penguin.

Barth, Karl. 1956. Church Dogmatics II/1. Edinburgh: T\&T Clark.

Barth, Karl. 1961. Church Dogmatics IV/3i. Edinburgh: T\&T Clark.

Barth, Karl. 1962. Church Dogmatics IV/Bii. Edinburgh: T\&T Clark.

Barth, Karl. 1968. Church Dogmatics IV/1. Edinburgh: T\&T Clark.

Bogghasian, Paul. 2006. Fear of Knowledge: Against Relativism and Constructivism. Oxford: Clarendon.

Frankfurt, Harry G. 2005. On Bullshit. Princeton: Princeton University Press.

Hovey, Craig. 2011. Bearing True Witness: Truthfulness in Christian Practice. Grand Rapids: Eerdmans.

Lewis, Andrew Zack. 2014. Read Him Again and Again: Repetitions of Job in Kierkegaard, Vischer and Barth. Eurgene: Pickwick. McIntyre, Lee. 2018. Post-Truth. Cambridge: MIT Press.

Oxford Languages. 2016. Word of the Year 2016. Available online: https://languages.oup.com/word-of-the-year/2016/ (accessed on 6 June 2021). 
Pinker, Stephen. 2018. Enlightenment Now: The Case for Reason, Science, Humanism and Progress. London: Penguin.

Rasmussen, Arne. 2012. Science and Salvation: George Lakoff and Steven Pinker as Secular Political Theologians. Modern Theology 28: 197-228. [CrossRef]

Ticciati, Susannah. 2005. Job and the Disruption of Identity: Reading Beyond Barth. London: T\&T Clark.

Williams, Rowan. 2016. Being Disciples. London: SPCK.

Zahl, Simeon. 2020. The Holy Spirit and Christian Experience. Oxford: Oxford University Press. 